Ann. Biol. anim. Bioch. Biophys., 1978, 18 (6), 1325-1331.

\title{
Glucocortico:ds and mammary gland development : mammary cell multiplication and hypertrophy in rabbit
}

par J. FÈVRE, L.-M. HOUDEBINE *

Station de Physiologie animale

* Laboratoire de Physiologie de la Lactation I.N.R.A., 78350 jouy-en-Josas, France.

Technical assistance of Nicole VERMEIRE, B. MORET, Claudine PUISSANT

Summary. Previous work demonstrated that glucocorticoids were able to initiate marked multiplication and hypertrophy of the mammary cell during pregnancy in rabbit, essentially when injected from day 19 onwards. In this report glucocortoid injections during pregnancy induced a drop of progesterone. However, this effect was not evidenced in early pregnancy and its intensity increased as pregnancy proceeded. It was concluded that this glucocorticoid action was mediated through a decrease of progesterone.

\section{Introduction.}

Prolactin effects on the mammary cell are modulated by several hormones, including glucocorticoids which amplify some of these effects and progesterone which inhibits them (Denamur, 1971). Data on the role of glucocorticoids are partly conflicting. Indeed, when injected in the rabbit at any time during pregnancy, these steroids can stimulate lactose synthesis, whereas they induce significant mammary cell hypertrophy only when injected from day 19 onwards (Denamur, 1964).

These variations in response to glucocorticoids as a function of the stage of pregnancy have been considered to reflect the level of circulating prolactin, assumed to rise during the last third of pregnancy (Denamur, 1964). A recent work demonstrated however that such a rise does not take place in the rabbit (Durand and Djiane, 1977) which seems devoid of a potent placental lactogen (Durand and Djiane, 1977). Thus, at least in this species, the hypothesis mentioned above does not appear to be substantiated by the experimental data.

On the other hand, glucocorticoids provoked abortion in the rabbit when injected during the last third of pregnancy (Adams and Wagner, 1969). Abortion was accompanied by a drop of progesterone level (Kendall and Liggins, 1972 ; Davies ef al., 1976), and injections of progesterone simultaneously with glucocorticoids prevented

* Address for correspondance. 
abortion (Nathanielsz and Abel, 1973). These observations prompted us to determine whether the differences of glucocorticoid action at various stages of pregnancy could be ascribed to a variable capacity of these steroids to decrease progesterone levels throughout pregnancy. For this purpose, natural glucocorticoid variations during pregnancy were re-evaluated and progesterone level was estimated during hydrocortisone acetate treatment.

\section{Material and methods.}

Pregnant New-Zealand rabbits were used; the day of mating was considered as day 0 of pregnancy.

Hydrocortisone acetate (Roussel) was injected intramuscularly at 9 a.m. and 7 p.m. Blood samples were collected by cardiac puncture at $9 \mathrm{a} . \mathrm{m}$. just before the injections of hydrocortisone acetate.

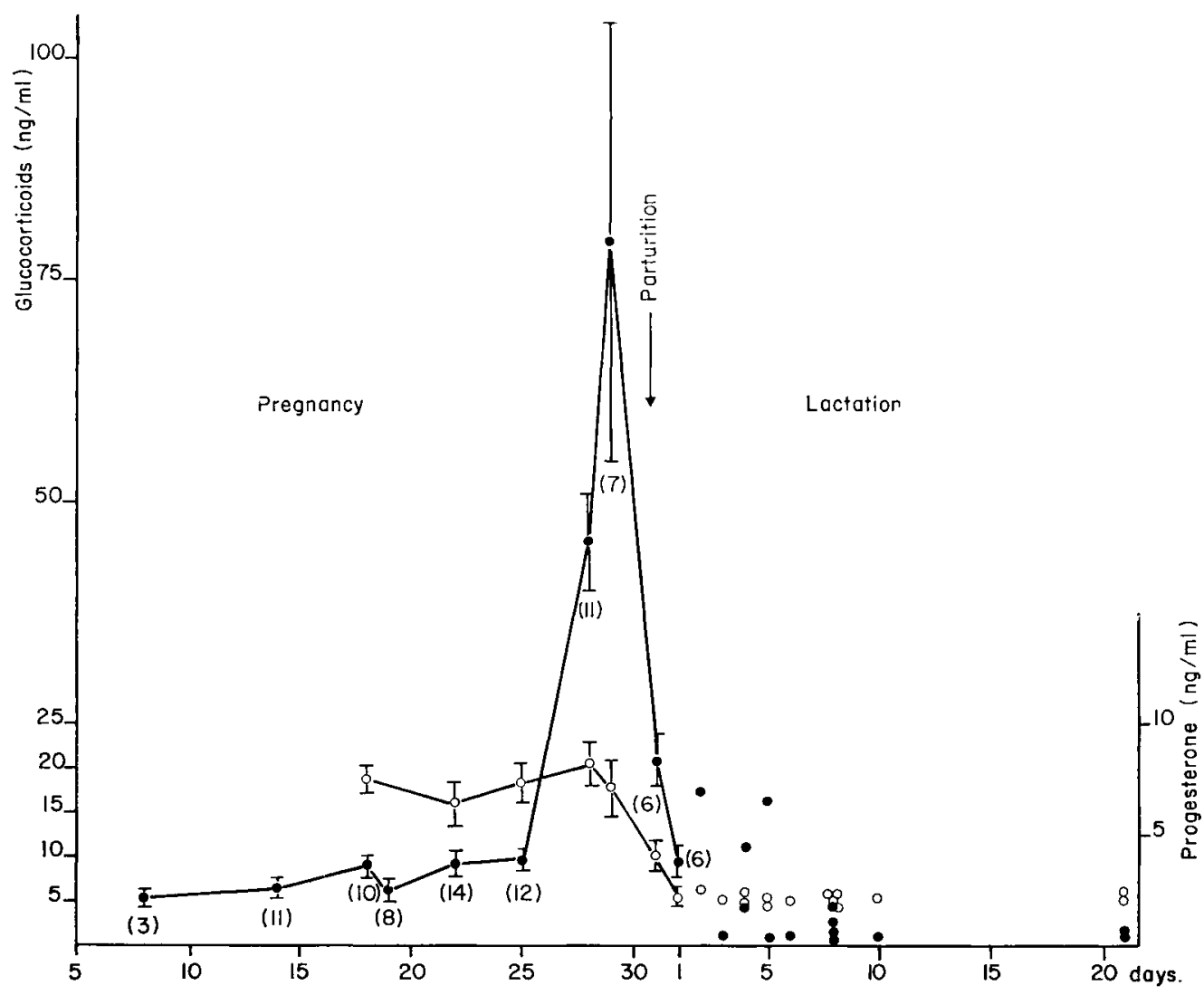

FIG. 1. - Glucocorticoid and progesterone variations during pregnancy in rabbit.

- total glucocorticoid, o progesterone.

The vertical bars represent the standard error of the mean. The numbers between brackets indicate the number of does per group. 
Total glucocorticoids were estimated by a method previously published and relying on binding to dog Cortisol Binding Protein (CBG) (Bosc and Fèvre, 1977). In the conditions used, CBG did not bind progesterone, and CBG affinity for corticosterone was about one-half of the affinity for cortisol. Glucocorticoids bound to blood protein were determined after specific elimination of the free glucocorticoid by adsorption on activated charcoal (Heyns et al., 1967).

Progesterone was estimated by a radioimmunoassay as described earlier (Bosc and Fèvre, 1975).

\section{Results.}

\section{Glucocorticoid variations during pregnancy.}

Glucocorticoid variations during pregnancy in the rabbit have already been documented (Gala and Westphal, 1967 ; Mulay ef al., 1973 ; Baldwin and Stabenfeldt, 1974). However, the data of previous reports conflict in some respects. Results of the present work indicate that a slight increase takes place between days 14 and 25 of pregnancy. After this period, a very marked increase occurs with a maximum at day 29. At the time of parturition and during the first days of lactation, the level returns to a relatively low value (fig. 1). The proportion of the hormone bound to blood protein slightly increased with the peak of total glucocorticoids (table 1). This is in agreement with the enhanced glucocorticoid binding capacity of serum previously mentioned at this stage of pregnancy (Gala and Westphal, 1967). The pattern of glucocorticoid variation between day 25 and parturition is compatible with the data of Mulay et al. (1973) and Baldwin and Stabenfeldt (1974). In the rabbit, progesterone is known to reach its maximum between days 14 and 16 of pregnancy. This maximum is followed by a slow decrease until day 26-28. Between day 28 and parturition, this decrease is abruptly accelerated (Challis ef al., 1973 ; Hilliard ef al., 1973 ; Baldwin and Stabenfeldt, 1974 ; Harrington and Rothermel, 1977). Thus, it appears that the two steroids exhibit opposite variations suggesting that the glucocorticoid increase is responsible for the progesterone decrease.

\section{TABLE 1}

Percentage of glucocorticoid bound to blood proteins during pregnancy and lactation.

The value for lactation was calculated from the whole data not taking into account the stage of lactation

\begin{tabular}{c|c|c|c|c|c|c|c}
\hline $\begin{array}{c}\text { Days of } \\
\text { pregnancy }\end{array}$ & 18 & 22 & 25 & 28 & 29 & 31 & Lactation \\
\hline p. $100 \ldots \ldots$ & $81.8 \pm 3.43$ & $81.00 \pm 3.34$ & $87.22 \pm 1.10$ & $93.57 \pm 1.30$ & $98.50 \pm 1.5085 .50 \pm 2.60$ & $86.69 \pm 2.09$ \\
\hline
\end{tabular}

Progesterone variation during hydrocortisone acetate treatment.

Hydrocortisone acetate was injected for 4 to 5 days at three periods of pregnancy. Results of Fig. 2 indicate that the effects of these injections were different as pregnancy progressed. When injected from days 8 to 13, the glucocorticoid, even at high doses (7.5 mg/injection), did not prevent the progesterone increase. By contrast, when 
injected from days 14 to 18 or from days 18 to 22 , the glucocorticoid caused progesterone to decline. However, this fall of progesterone was significantly greater during the 18-22 day period than during the 14-18 day period. Doses of $3.75 \mathrm{mg}$ or $7.5 \mathrm{mg}$ exhibited only slightly different effects (not shown). These observations are in good agreement with the greater capacity of glucocorticoids to provoke abortion during late pregnancy.

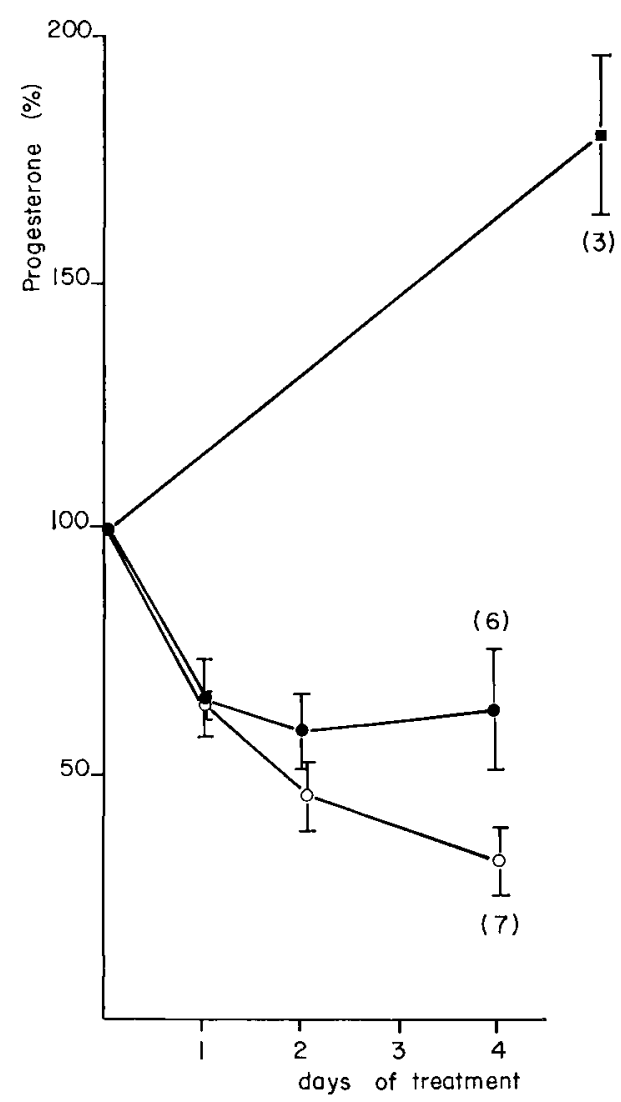

FIG. 2. - Variation of progesterone concentration during hydrocortisone acetate treatment of pregnant rabbits.

- $7.5 \mathrm{mg} /$ injection from day 8 to day 13 ,

- $3.75 \mathrm{mg} /$ injection from day 14 to day 18 ,

- $3.75 \mathrm{mg} /$ injection from day 18 to day 22.

Result are expressed as the percentage of progesterone concentration just before starting the treatment. The concentrations of progesterone before the first hydrocortisone acetate injection were in $\mathrm{ng} / \mathrm{ml}: 8.26 \pm 0.24,10.72 \pm 0.93$ and $12.18 \pm 1.23$, respectively. The numbers between brackets indicale the number of does per group.

\section{Conclusion and discussion.}

The data of the present report indicate that glucocorticoids rise slowly during pregnancy after day 14 and abruptly just before parturition with a peak at day 29. 
In addition, injections of hydrocortisone acetate induce a drop of progesterone, the intensity of which increases as pregnancy proceeds. These facts conform with the known capacity of glucocorticoids to initiate abortion or not according to the period of pregnancy (Adams and Wagner, 1969), and with glucocorticoid ability to enhance the activity of enzymes involved in progesterone inactivation (Flint ef al., 1975). These observations can be correlated with some known effects of glucocorticoids on mammary gland.

It is noteworthy that the slight variations of the two steroids between days 14 and 25 correspond to an increase in RNA and DNA contents (Denamur, 1963a), casein synthesis, casein mRNA (Shuster et al., 1976), lactose synthetase activity (Denamur and Delouis, 1972 ; Mellenberger and Bauman, 1974), lipid synthesis (Strong and Dils, 1972), prolactin receptors (Djiane ef al., 1977) and spermidine (Houdebine et al., 1978b). The peak of glucocorticoids at day 29 is not accompanied by any hypertrophy of the mammary cell (Denamur, 1963a). On the contrary, prolactin injected between days 24 and 29 proved to be less efficient, than earlier in pregnancy, for induction of hypertrophy as judged by the RNA/DNA ratio (Denamur, 1963b). This suggests that the high glucocorticoid level prevents possible hypertrophy of the mammary cell, as in a similar situation when high doses of hydrocortisone acetate $(7.5 \mathrm{mg} /$ injection twice a day) are injected with prolactin into pseudopregnant rabbits (unpublished data). Moreover, it appears that most of the hypertrophy takes place between parturition and day 10 of lactation, when the glucocorticoid level has returned to a relatively low value, progesterone has dropped and prolactin has risen (Durand and Djiane, 1977). This suggests that the glucocorticoid peak is not a major trigger inducing hypertrophy of the mammary cell in rabbit.

Hydrocortisone acetate injected into pregnant rabbits is able to induce a significant multiplication and hypertrophy of the mammary cell only after day 18 of pregnancy (Denamur, 1964). This appears to be related to the capacity of the glucocorticoid to decrease progesterone.

In addition, it has been shown in other species that this drop of progesterone may have led to a parallel enhancement of prolactin (Vermouth and Deis, 1974 ; Kann et al., 1978).

Apart from these indirect effects, the antagonism between the two steroids may be mediated by a direct competition in the mammary cell, for instance towards progesterone receptor binding.

Glucocorticoids have been demonstrated to amplify the action of prolactin on casein synthesis by favouring the accumulation or casein mRNA. This amplification, observed both in vivo and in organ culture, was not accompanied by hypertrophy of the mammary cell (Devinoy and Houdebine, 1977 ; Devinoy et al., 1978). However, when associated with moderate doses of prolactin (12.5 IU or $50 \mathrm{IU}$ injected twice a day into pseudopregnant rabbits) over a period of 5 days, hydrocortisone acetate $(3.75 \mathrm{mg} / \mathrm{injec}-$ tion twice a day) led to an increase of the mammary gland total RNA and DNA contents which were slightly but significantly higher than with prolactin alone (unpublished data). On the other hand, glucocorticoids proved to be involved in maintaining mammary gland activity and structure (Houdebine ef al., 1978a). Thus, the participation of glucocorticoids in mammary gland development might be mediated to a large extent by a stabilization of some cellular components, the synthesis of which is under 
prolactin control. Such a mechanism might account for the fact that the moderate glucocorticoid effect on cellular hypertrophy, which takes place in the pseudopregnant rabbit at a time when progesterone has spontaneously dropped (Harrington and Rothermel, 1977), can be observed only after long hormonal treatments. This interpretation is also compatible with the fact that prolactin alone when injected into adrenalectomized rabbits exhibits a significantly reduced capacity to support the hypertrophy of the mammary cell (Denamur, 1964).

Independently of these mechanisms, glucocorticoids may facilitate mammary gland development by participating in the control of spermidine synthesis (Oka and Perry, 1974 ; Houdebine ef al., 1978b).

Reçu en avril 1978. Accepté en juin 1978.

Acknowledgements. - The authors are indebted to professor $\mathrm{H}$. Clauser for helpful advice in editing the manuscript. The work was supported by grants from the Délégation Générale à la Recherche Scientifique et Technique and the Centre National de la Recherche Scientifique.

Résumé. Il a été démontré que les glucocorticoïdes ne peuvent induire de façon significative la multiplication et l'hypertrophie de la cellule mammaire chez la lapine gestante que lorsqu'ils sont injectés à partir du $19 \mathrm{e}$ jour de la gestation. Dans le présent rapport, il est montré que les glucocorticoïdes injectés pendant la gestation induisent une chute de la progestéronémie. Toutefois, cet effet n'a pas lieu en début de gestation et il devient de plus en plus accentué au fur et à mesure qu'on se rapproche de la parturition. L'action des glucocorticoïdes sur la multiplication et l'hypertrophie de la cellule mammaire résulte donc d'un abaissement de la progestéronémie.

\section{References}

ADAMS W. M., WAGNER W. C., 1969. The elective induction of parturition in cattle, sheep and rabbits. J. am. vet. med. Ass. 154, 1396-1397.

BALDWIN D. M., STABENFELDT G. H., 1974. Plasma levels of progesterone, cortisol and corticosterone in the pregnant rabbit. Biol. Reprod., 10, 495-501.

BOSC M., FÈVRE J., 1975. Evolution de la progestéronémie chez la brebis en fin de gestation après destruction de l'hypophyse fœetale. Effet d'une administration de dexaméthasone. C. R. Acad. Sci. Paris, sér. D., 281, 559-562.

BOSC M., FÈVRE J., 1977. Evolution de la cortisolémie au cours de la première semaine de vie chez le veau et chez l'agneau. C. R. Acad. Sci. Paris, sér. D, 284, 2373-2376.

CHALLIS J. R. G., DAVIES I. J., RYAN K. J., 1973. The concentration of progesterone, estrone and estradiol-17 $\beta$ in the plasma of pregnant rabbits. Endocrinology, 93, 971-976.

CHIBOKA O., CASIDA L. E., FIRST N. L., 1977. Role of rabbit fetuses and placentas in the maintenance of gestation and parturition, J. Anim. Sci., 46, 776-783.

DAVIES I. J., YOSHINAGA K., RYAN K. J., 1976. The effects of combined dexaméthasone and indomethacine treatment on the outcome of pregnancy in the rabbit. Biol. Reprod., 15, 551554.

DENAMUR R., 1963a. Les acides nucléiques de la glande mammaire pendant la gestation et la lactation chez la lapine. C. R. Acad. Sci. Paris, 256, 4748-4750.

DENAMUR R., 1963b. Croissance mammaire et lactogenèse induites par la prolactine chez la lapine en gestation. C. R. Acad. Sci. Paris, 257, 1548-1551.

DENAMUR R., 1964. Les acides nucléiques et les nucléotides libres de la glande mammaire pendan la lactogenèse et la galactopoïèse. Excerpta med., Int. Congr. Ser., no 83, 434-462. 
DENAMUR R., 1971. Hormonal control of lactogenesis. J. Dairy Res., 38, 237-264.

DENAMUR R., DELOUIS C., 1972. Effects of progesterone and prolactin on the secretory activity and the nucleic acid content of the mammary gland of pregnant rabbits. Acta endocr., 70, 603-618.

DEVINOY E., HOUDEBINE L. M., 1977. Effects of glucocorticoids on casein gene expression in the rabbit. Europ. J. Biochem., 75, 411-416.

DEVINOY E., HOUDEBINE L. M., DELOUIS C., 1978. Role of prolactin and glucocorticoids in the expression of casein genes in rabbit mammary gland organ culture. Quantification of casein mRNA. Biochem. biophys. Acta, 517, 360-366.

DJIANE J., DURAND P., KELLY P. A., 1977. Evolution of prolactin receptors in rabbit mammary gland during pregnancy and lactation. Endocrinology, 100, 1348-1356.

DURAND P., DJIANE J., 1977. Lactogenic activity in the serum of rabbit during pregnancy and early lactation. J. Endocr., 75, 33-42.

FLINT A. P., ANDERSON A. B. M., STEELE P. A., TURNBULL A. C., 1975. The mechanism by which foetal cortisol controls the onset of parturition in the sheep. Biochem. Soc. Trans., 3, 1189-1194.

GALA R. R., WESTPHAL U., 1967. Corticoid-binding activity in serum of mouse, rabbit and guinea-pig during pregnancy and lactation : possible involvement in the initiation of lactation Acta endocr., 55, 47-61.

HARRINGTON F. E., ROTHERMEL J. D., 1977. Daily changes in peripheral plasma progesterone concentrations in pregnant and pseudopregnant rabbits. Life Sci., 20, 1333-1340.

HEYNS W. H., VAN BAELEN H., DE MOOR P., 1967. Study of steroid-protein binding by means of competitive adsorption : application to cortisol binding in plasma. Clin. chim. Acta, 18, 361370.

HILLIARD J., SCARAMUZZI R. J., PENARDI R., SAWYER C. H., 1973. Progesterone, estradiol and testosterone levels in ovarian venous blood of pregnant rabbits. Endocrinology, 93, 1235-1238.

HOUDEBINE L. M., DEVINOY E., DELOUIS C., 1978a. Stabilization of casein mRNA by prolactin and glucocorticoids. Biochimie, 60, 57-63.

HOUDEBINE L. M., DEVINOY E., DELOUIS C., 1978b. Role of spermidine in casein gene expression in the rabbit. Biochimie (in press).

KANN G., CARPENTIER M. C., FEVRE J., MARTINET J., MAUBON M., MEUSNIER C., PALY J., VERMEIRE N., 1978. Lactatation and prolactin in sheep ; role of prolactin in initiation of milk secretion, 201-212. In ROBYN C., HARTER M. Progress in prolactin physiology and pathology. Elsevier/North-Holland. Biomedical Press.

KENDALL J. Z., LIGGINS G. C., 1972. The effect of dexaméthasone on pregnancy in the rabbit. J. Reprod. Ferf., 29, 409-413.

MELLENBERGER R. N., BAUMAN D. E., 1974. Metabolic adaptations during lactogenesis. Lactose synthesis in rabbit mammary tissue during pregnancy and lactation. Biochem. J., 142, 659665.

MULAY S., GIANNOPOULOS G., SOLOMON S., 1973. Corticosteroid levels in the mother and fetus on the rabbit during gestation. Endocrinology, 93, 1342-1348.

NATHANIELSZ P. W., ABEL M., 1973. Initiation of parturition in the rabbit by maternal and foetal administration of cortisol : effect of rate and duration of administration : suppression of delivery by progesterone. J. Endocr., 57, 47-54.

OKA T., PERRY J. W., 1974. Spermidine as a possible mediator of glucocorticoid effect on milk protein synthesis in mouse mammary epithelium in vitro. J. biol. Chem., 249, 7647-7652.

SHUSTER R., HOUDEBINE L. M., GAYE P., 1976. Studies on the synthesis of casein mRNA during pregnancy in the rabbit. Europ. J. Biochem., 71, 193-199.

STRONG C. R., DILS R., 1972. Fatty acid biosynthesis in rabbit mammary gland during pregnancy and early lactation. Biochem. J., 128, 1303-1309.

VERMOUTH N. T., DEIS R. P., 1974. Prolactin release and lactogenesis after ovariectomy in pregnant rats : effect of ovarian hormones. J. Endocr., 63, 13-20. 